\title{
Shengmai-san Enhances Antioxidant Potential in C2C12 Myoblasts Through the Induction of Intracellular Glutathione Peroxidase
}

\author{
Hiroshi Nishida ${ }^{1}$, Haruyo Ichikawa ${ }^{1}$, and Tetsuya Konishi ${ }^{1, *}$ \\ ${ }^{1}$ Department of Applied Life Sciences, Niigata University of Pharmacy and Applied Life Sciences, Niigata 956-8063, Japan
}

Received August 21, 2007; Accepted October 16, 2007

\begin{abstract}
Cellular and tissue injury associated with reactive oxygen species (ROS) has been reported in many kinds of disorders. While the antioxidant enzymes play critical roles in inhibiting the ROS-mediated injury, glutathione peroxidase (GPx) is scavenging hydroperoxides including $\mathrm{H}_{2} \mathrm{O}_{2}$. We previously reported that Shengmai-san (SMS), a traditional Chinese medicine, prevented ischemia/reperfusion injury of the brain and other organs in rats. To clarify the effect of SMS on intracellular responses of muscle cells against oxidative stress, $\mathrm{C} 2 \mathrm{C} 12$ myoblasts were subjected to $\mathrm{H}_{2} \mathrm{O}_{2}$ abuse. SMS pre-incubation prevented the decreasing cell viability after $\mathrm{H}_{2} \mathrm{O}_{2}$ treatment. The accumulations of cellular protein carbonyl associated with apoptotic cell death were also inhibited by the SMS pre-incubation prior to oxidative damage induction. At the same time, enhanced activity, protein, and mRNA expression levels of GPx were observed in cells pre-incubated with SMS prior to $\mathrm{H}_{2} \mathrm{O}_{2}$ abuse. Moreover, intracellular GSH was subsequently decreased after $\mathrm{H}_{2} \mathrm{O}_{2}$ treatment. These findings suggest that SMS improved the antioxidant capacity against acute oxidative stress through the constitutive enhancement of GPx expression in $\mathrm{C} 2 \mathrm{C} 12$ myoblasts. Because of its antioxidative property, SMS might be useful not only for the oxidative damage associated diseases but also for the transplantation of myoblasts into muscular dystrophy patients.
\end{abstract}

Keywords: oxidative stress, Shengmai-san, glutathione peroxidase, skeletal muscle

\section{Introduction}

The cell injury associated with reactive oxygen species (ROS) has been implicated in a wide variety of muscle diseases and pathologic conditions (1). Duchenne muscular dystrophy (DMD), a severe progressive muscle disease due to a mutation of the dystrophin gene, and also the mdx mouse, an animal model for DMD, exhibits the absence of the membrane-associated protein dystrophin (2). Besides the functional defect of dystrophin, recent studies have shown that the muscular dystrophy is associated with an increase in oxidative stress $(3-6)$. The redox status in the degrading muscles of patients is more oxidative compared to those of other organs. Muscular stem cells including exogenously reconstituted myoblasts with proteins such as dystrophin

*Corresponding author. konishi@nupals.ac.jp

Published online in J-STAGE: December 1, 2007

doi: 10.1254/jphs.FP0071371 are expected to have clinical application to muscular dystrophy as an effective cell therapy $(7,8)$. It will be quite important to enhance the antioxidant potentials of myoblasts or stem cells against oxidative stress conditions, especially for the purpose of regeneration of muscle such as in the cell or gene therapies. Hence, the skeletal muscles, not only matured myofibrils and myotubes but also myoblasts and myogenic stem cells, are clinically awaited to have high capacity against oxidative stress conditions.

Skeletal muscle is susceptible to ROS injury even under physiological condition because there are rapid changes in energy supply and oxygen flux during the contraction (9). Moreover, extreme exercise leads to muscle injury by increased production of ROS $(10,11)$. Thus, the enhancement of antioxidative potential of skeletal muscles will have an advantage in preparing for the redox imbalance occurring under exercise conditions or in diseases.

Glutathione peroxidase (GPx) plays a critical role to 
inhibit tissue or cellular damages caused by oxidative stress in collaboration with other antioxidants and enzymes $(12,13)$. By either the Fenton or Harber-Weiss type reactions using GSH as a co-substrate, GPx scavenges hydroperoxides including $\mathrm{H}_{2} \mathrm{O}_{2}$, which can otherwise produce hydroxyl radicals, one of the most aggressive ROS (14). Therefore, the induction of GPx expression is critical to attenuate cellular antioxidant potential and thus constitutively enhanced GPx expression might be valuable in terms of prevention or management of disease associated with oxidative stress. In this sense, traditional medicine formula used for disease prevention is an interesting target of study because their basic function is to modulate the physiological resistance against exogenous stimuli including oxidative stress through manipulating cellular processes (15).

Recent reports demonstrated that Shengmai-san (SMS), a traditional Chinese medicine formula, significantly prevented the oxidative damage in heart, brain, and other tissues $(4,16)$. We also showed that SMS had high antioxidant potential to prevent cerebral oxidative damages induced by ischemia-reperfusion treatment in experimental animals (17). In the experiments, SMS pretreatment inhibited the GPx activity loss that occurred after the ischemia-reperfusion stress in rats as well as the prevention of protein carbonyl formation and TBARS in many organs.

Here, we demonstrate further mechanisms of the antioxidant effect of SMS that improved antioxidative potential against $\mathrm{H}_{2} \mathrm{O}_{2}$-induced oxidative stress through increases in the expression of intracellular GPx and its activity in $\mathrm{C} 2 \mathrm{C} 12$ myoblasts.

\section{Materials and Methods}

\section{Preparation of Shengmai-san (SMS)}

The SMS decoction was prepared as described previously (18). The three composite herbs of SMS: Panax ginseng (48 g), Ophiopogon japonicus (48 g), and Schisandra chinesis ( $24 \mathrm{~g})$ were kindly provided by Kotaro Kanpo Co., Ltd., Osaka; they were kept in a $-80^{\circ} \mathrm{C}$ freezer until used. The specimen numbers of herbs (Ginseng: 06100501, Ophiopogon japonicus: 06190101, Schisandra chinesis: 06020301) for this study were recorded and stored for 10 years at Niigata University of Applied Life Sciences. The herbs were suspended in $1200 \mathrm{ml}$ distilled water, soaked for $1 \mathrm{~h}$, and then boiled for $1 \mathrm{~h}$ in each experiment. After the filtration, the extracts were used for the addition to the culture. The concentration of SMS was calculated and indicated as weight per volume $(\mathrm{w} / \mathrm{v})$ of dry herb into medium. The quality control of SMS is secured by HPLC analysis with standard solutions of active ingredients (18). To estimate the pharmacological effect of SMS, $\alpha$-tocopherol ( $\alpha$-Toc), and $N$-acetyl cysteine (NAC) were compared as antioxidant references (positive control) in the present study (Fig. 1C).

\section{Cell culture}

C2C12 myoblasts were maintained in Dulbecco's modified Eagle medium (Sigma Chemical Co., St. Louis, MO, USA) supplemented with $10 \%$ fetal bovine serum (FBS, Sigma). The cells were seeded in $\phi 60-\mathrm{mm}$ dishes (Nalge Nunc Int., Rochester, NY, USA) at a density of $1 \times 10^{4}$ cells $/ \mathrm{cm}^{2}$. All cultures were kept in a humidified atmosphere of $95 \%$ air and $5 \% \mathrm{CO}_{2}$ at $37^{\circ} \mathrm{C}$. Initially, the cells were cultured for 1 day in $3 \mathrm{ml}$ of DMEM, which was supplemented with $100 \mathrm{U} / \mathrm{ml}$ penicillin (Invitrogen, Carlsbad, CA, USA), $100 \mathrm{U} / \mathrm{ml}$ streptomycin (Invitrogen), and 10\% FBS. In the first experiment, $\mathrm{C} 2 \mathrm{C} 12$ myoblasts were cultivated for $24 \mathrm{~h}$ with or without SMS (Kotaro Kanpo Co., Ltd.). The cultures were washed with $3 \mathrm{ml}$ serum-free DMEM; and subsequently, the culture mediums were replaced with $0.1,1,10$, and $100 \mathrm{mM}$ of $\mathrm{H}_{2} \mathrm{O}_{2}$ (Wako Pure Chemical Co., Osaka). Cultured myoblasts dissociated by $1 \mathrm{~h}$ after $\mathrm{H}_{2} \mathrm{O}_{2}$ addition. The control was cultured with $0 \mathrm{mM}$ of $\mathrm{H}_{2} \mathrm{O}_{2}$ in DMEM. In the second experiment, $1 \mathrm{mM} \mathrm{H}_{2} \mathrm{O}_{2}$ was used.

\section{Cell viability}

Cell viability was determined by the MTT [3,(4,5dimethylthiazol-2-yl)2,5-diphenyltetrazolium bromide] method as described previously (19). The myoblasts were cultured with or without SMS for $24 \mathrm{~h}$ after the pre-incubation in GM for $24 \mathrm{~h}$ in 96-well multi-titer plates. Then $\mathrm{H}_{2} \mathrm{O}_{2}$ was added to the culture and incubated for $30 \mathrm{~min}$. After replacing the medium for $0.05 \%$ MTT with GM, the myoblasts were incubated for $4 \mathrm{~h}$ at $37^{\circ} \mathrm{C}$. The cells were lysed in the lysing buffer $[20 \%$ SDS, $50 \% N, N$-dimethyl formamide (DMF), $\mathrm{pH} 4.7]$, and the absorbance at $570 \mathrm{~nm}$ was measured by a microplate reader.

\section{In situ cell death detection}

C2C12 myoblasts were seeded onto a Lab-tech chamber (Nalge Nunc). Cells were fixed for 5 min with cold methanol and then rehydrated with PBS. Slides were rinsed with PBS and incubated in permeabilization solution $(0.1 \%$ Triton $\mathrm{X}-100,0.1 \%$ sodium citrate) for $2 \mathrm{~min}$ on ice. Apoptotic cells were detected by the TUNEL method using the In Situ Cell Death Detection Kit (Roche Molecular Biochemicals, Mannheim, Germany). The cells were examined and photographed under a confocal laser microscope (Bio-Rad, Hercules, CA, USA) after nuclei were counterstained with $1 \mathrm{mM}$ 
Propidium iodide (PI, Sigma). At least 500 cells in 6 randomly selected fields were counted for each treatment.

\section{Protein carbonyl}

Protein carbonyls were determined in $\mathrm{C} 2 \mathrm{C} 12$ myoblasts by measuring the reactivity of carbonyl derivatives with 2,4-dinitrophenylhydrazine (DNPH) as previously described (20). In brief, cells were harvested with ice cold PBS, and the reaction with $10 \mathrm{mM}$ DNPH in $2 \mathrm{~N} \mathrm{HCl}$ was performed for $1 \mathrm{~h}$ at $37^{\circ} \mathrm{C}$ in a dark place. The aliquoted proteins were washed with ethanol - ethyl acetate $(1: 1)$. The precipitated proteins were dissolved in $6 \mathrm{M}$ guanidine at $\mathrm{pH} 2.5$. The carbonyl content was determined by the absorbance at $360 \mathrm{~nm}$ with a UV-spectrophotometer.

\section{GPX activity}

GPX activity was determined according to the method of Albercht (21). Briefly, an aliquot of cell homogenate in $0.05 \mathrm{M}$ phosphate buffer containing $1.15 \%(\mathrm{w} / \mathrm{v}) \mathrm{KCl}$ was mixed in a cuvette with $935 \mu \mathrm{l}$ of the coupling solution $\left(2.0 \mathrm{mM}\right.$ EDTA-2Na, $1.0 \mathrm{mM} \mathrm{NaN}_{3}, 1 \mathrm{mM}$ $\mathrm{GSH}, 0.2 \mathrm{mM}$ NADPH, and $100 \mathrm{U} / \mathrm{ml} \mathrm{GSH}$ reductase in $50 \mathrm{mM}$ Tris-HCl, $\mathrm{pH}$ 7.6). Kinetic decay of NADPH absorbance at $340 \mathrm{~nm}$ was measured after the addition of $25 \mu \mathrm{l}$ of $1.0 \mathrm{mM} \mathrm{H}_{2} \mathrm{O}_{2}$ as substrate using a spectrophotometer.

\section{Immunocytochemistry}

For immunofluorescence analysis, $\mathrm{C} 2 \mathrm{C} 12$ myocblasts were seeded onto a Lab-tech chamber. After the incubation, the cells were fixed for $5 \mathrm{~min}$ with cold methanol, rehydrated with PBS, and then incubated in PBS containing $0.05 \%$ saponin. Chamber slides were blocked for $15 \mathrm{~min}$ in normal goat serum (in PBS) and incubated for $1 \mathrm{~h}$ with FITC conjugated antibody (anti GPx-1 Ig; Biogenesis, Inc., NH, USA) for immunofluorescent labeling. For the GPx-1 staining, antibody was diluted 1:200. After extensive washes, nuclei were counterstained with PI. The cells were examined and photographed under a confocal laser microscope (Bio-Rad).

\section{Immunoblotting}

Cells were harvested by scraping into ice cold phosphate-buffered saline (PBS), and extracts were prepared by lysis buffer containing $10 \mathrm{mM}$ Tris (pH 7.4), $1 \mathrm{mM}$ EDTA, $1 \mathrm{mM}$ EGTA, $150 \mathrm{mM} \mathrm{NaCl}$, $0.5 \%$ NP-40, $1 \%$ Triton X-100, $1 \mathrm{mM}$ phenylmethanesulfonyl fluoride (PMSF), $2 \mu \mathrm{g} / \mathrm{ml}$ pepstatin, $2 \mu \mathrm{g} / \mathrm{ml}$ aprotinin, and $p, p^{\prime}$-dichlorodiphenyltrichloroethane (DTT). Protein concentrations of extracts were determined by a protein assay kit (Bio-Rad). Cell lysates were applied to $10 \%$ SDS polyacrylamide gel electrophoresis (PAGE) and transferred to nitrocellulose membrane. For immunoblotting, the membrane was blocked with $5 \%$ skim milk in Tris-buffered saline containing $0.1 \%$ Triton X-100 (TBS-T) for $1 \mathrm{~h}$ at room temperature. As the primary antibody, anti-GPx-1 rabbit anti serum (N-20; Santa Cruz Biotechnologies, Santa Cruz, CA, USA) and anti $\beta$-tubulin monoclonal antibody (T4026, Sigma), for even loading, were used. After the incubation with primary antibodies for $16 \mathrm{~h}$ at $4^{\circ} \mathrm{C}$, the membrane was washed 3 times with TBS-T followed by the incubation with second antibody (Zymed) for $1 \mathrm{~h}$ at room temperature. Target proteins were visualized by an ECL reaction kit (Amersham, Piscataway, NJ, USA) and chemiluminescence film (Amersham).

\section{Enzyme-linked immunosorbent assay (ELISA)}

GPx expression level was compared by using ELISA. An aliquot of cell lysates was applied to each well of a microtiter plate and incubated at $4^{\circ} \mathrm{C}$ for $16 \mathrm{~h}$. The plate was washed 5 times with PBS and incubated with TBS (20 mM-Tris, $500 \mathrm{mM}-\mathrm{NaCl}$ ) solution containing $1 \%$ bovine serum albumin for $1 \mathrm{~h}$. Polyclonal antibody against GPx-1 (sheep IgG, Biogenesis) was applied to each well and incubated for $3 \mathrm{~h}$. After washing again, the plate was further incubated for $1 \mathrm{~h}$ with goat anti-sheep IgG (Sigma) conjugated with alkaline phosphatase. After washings with PBS, substrate kit (Bio-Rad) solution was added to each well of the plate and the absorbance at $405 \mathrm{~nm}$ was determined after the mixtures were allowed to stand for $30 \mathrm{~min}$ at $37^{\circ} \mathrm{C}$

Reverse transcription polymerase chain reaction (RT$P C R)$

To examine the effect of SMS on GPx-1 gene expression, quantitative RT-PCR was performed with the total RNA from the cultured $\mathrm{C} 2 \mathrm{C} 12$ myoblasts. Briefly, the total RNA was prepared by the method of acid guadinium-phenol-chloroform (AGPC) (22). For the synthesis of cDNA, the total RNA $(1 \mu \mathrm{g})$ was reversetranscribed for $1 \mathrm{~h}$ at $42^{\circ} \mathrm{C}$ in the reaction mixture $(20 \mu \mathrm{l})$ containing $50 \mathrm{mM}$ Tris- $\mathrm{HCl}$ (pH 8.3), $40 \mathrm{mM} \mathrm{KCl}$, $3 \mathrm{mM} \mathrm{MgCl}, 1 \mathrm{mM}$ DTT, $0.5 \mathrm{mM}$ each of dNTPs, $1.25 \mu \mathrm{g}$ of oligo(dT) $)^{12-18}$, and 500 Units of Superscript $\mathrm{II}^{\mathrm{TM}}$ (Invitrogen). PCR was performed under the following conditions: 33 cycles amplification with the following sequential process (denatured at $94^{\circ} \mathrm{C}, 30 \mathrm{~s}$; annealed at $55^{\circ} \mathrm{C}, 30 \mathrm{~s}$; extended at $72^{\circ} \mathrm{C}, 1 \mathrm{~min}$ ) using the primer pairs for GPx-1 (forward: 5'-TCGGTTTC CCGTGCAATCAGTTC-3', reverse: 5'-GAGTGCAGC CAGTAATCACCAAG-3'). The extent of GPx gene expression was normalized against the expression level of a house keeping gene, glyceraldehyde-2-phosphate 
dehydrogenase (GAPDH). The PCR amplification of GAPDH mRNA was examined by the RT-PCR kit (Toyobo Co., Ltd., Osaka) with the following primers: forward: 5'-TCCACCACCCTGTTGCTGTA-3', reverse: 5'-ACCACAGTCCATGCCATCAC-3'. The PCR products were separated by agarose gel electrophoresis (1\% agarose; Nacalai Tesque, Inc., Kyoto) to confirm the target product of PCR for each reaction. For quantitative evaluation of the gene expression levels, the samples were analyzed by real-time RT-PCR before the products became saturated, and a relative frequency for the expression of GPx gene against GAPDH gene was calculated for standardization.

\section{Cellular GSH levels}

GSH level in C2C12 myoblasts was determined by the fluorescence method using monochlorobimane (MBCL) as described (23). C2C12 cells were incubated in a 96 well microtiter plate at the density of $2 \times 10^{5}$ cells per well with or without SMS for $24 \mathrm{~h}$; then the cells were treated with $\mathrm{H}_{2} \mathrm{O}_{2}$ in serum-free DMEM for $1 \mathrm{~h}$. After the extensive washing with KRB buffer $(1.3 \mathrm{mM}$ $\mathrm{CaCl}_{2}, 1.3 \mathrm{mM} \mathrm{MgSO}, 0.3 \mathrm{mM} \mathrm{KH}_{2} \mathrm{PO}_{4}, 131 \mathrm{mM}$ $\mathrm{NaCl}, 5 \mathrm{mM} \mathrm{KCl}$, and $20 \mathrm{mM}$ HEPES, $\mathrm{pH} 7.4), \mathrm{C} 2 \mathrm{C} 12$ myoblasts were lysed by $0.1 \%$ Triton-X100 in KRB buffer for $10 \mathrm{~min}$ at room temperature. The formation of the fluorescent MBCL-GSH complex was monitored after the addition of reaction buffer $(0.04 \mathrm{U} / \mathrm{ml}$ glutathione $S$-transferase and $50 \mu \mathrm{M}$ MBCL in KRB buffer) at an excitation wavelength of $395 \mathrm{~nm}$ and the emission wavelength of $470 \mathrm{~nm}$ using a microplate spectrofluorometer (Fluoroskan Ascent, Labsystems, MA, USA). The results were expressed as the percent of MBCL fluorescence relative to the control.

\section{Statistics}

Statistical analysis was performed by the General Linear Model procedure of SAS (1995) in conjugation with the Duncan's multiple range tests. The level of statistical significance was taken as $P<0.05$.

\section{Results}

\section{Cell viability}

The viability of $\mathrm{C} 2 \mathrm{C} 12$ myoblasts after oxidative abuse by $\mathrm{H}_{2} \mathrm{O}_{2}$ was determined by MTT assay. $\mathrm{H}_{2} \mathrm{O}_{2}$ induced cell death occurred in a dose-dependent manner for the control cultures without SMS pre-incubation (Fig. 1A). In contrast, the cell death by $\mathrm{H}_{2} \mathrm{O}_{2}$ was alleviated by the pre-treatment of cells with $0.2 \%(\mathrm{w} / \mathrm{v})$ SMS. Although the cell viability was not significantly different at 0.25 and $4 \mathrm{mM} \mathrm{H}_{2} \mathrm{O}_{2}$, the cell death at $\mathrm{H}_{2} \mathrm{O}_{2}$ concentrations of $0.5-2 \mathrm{mM}$ was significantly inhibited
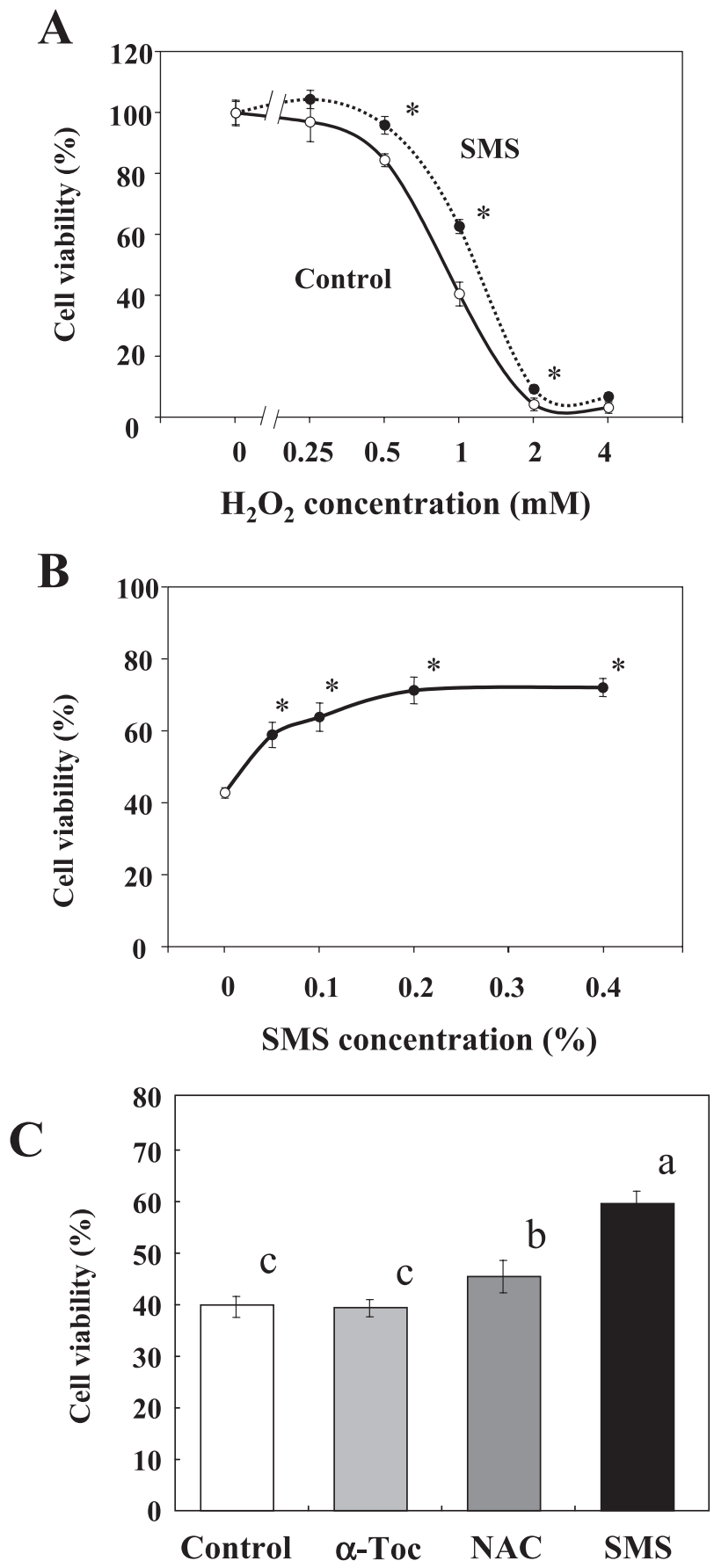

Fig. 1. Cell viability of $\mathrm{C} 2 \mathrm{C} 12$ myoblasts. A: Dose-dependent effect of $\mathrm{H}_{2} \mathrm{O}_{2}$ on cell viability of $\mathrm{C} 2 \mathrm{C} 12$ myoblasts. After the preincubation with or without SMS $(0.2 \%)$ for $24 \mathrm{~h}$, myoblasts cultures were treated with different concentrations of $\mathrm{H}_{2} \mathrm{O}_{2}$ as indicated for $1 \mathrm{~h}$. B: Effect of SMS concentration on cell viability of myoblasts. After the pre-incubation with SMS, at the indicated concentration, myoblasts cultures were treated with $1 \mathrm{mM} \mathrm{H}_{2} \mathrm{O}_{2}$ for $1 \mathrm{~h}$. Each value represents the mean \pm S.D. obtained from quadruplicate at least $(* P<0.05)$. C: The efficacy of SMS on cell viability was compared to $\alpha$-Tocopherol ( $\alpha$-Toc)- and $N$-acetyl cysteine (NAC)-treated cells. After the pre-incubation with SMS $(0.2 \%), \alpha$-Toc $(10 \mu \mathrm{M})$, or NAC $(5 \mathrm{mM})$ for $24 \mathrm{~h}$, cells were treated with $\mathrm{H}_{2} \mathrm{O}_{2}(1 \mathrm{mM})$ for $24 \mathrm{~h}$. Each value represents the mean \pm S.D. obtained from at least quadruplicate determinations $\left({ }^{\mathrm{abc}} \mathrm{P}<0.05\right)$. 
by SMS pre-treatment. At $1.0 \mathrm{mM} \mathrm{H}_{2} \mathrm{O}_{2}$, the viability difference was almost $20 \%$. The preventive effect of SMS on $\mathrm{H}_{2} \mathrm{O}_{2}$-induced cell death was examined at various concentrations of SMS at fixed $\mathrm{H}_{2} \mathrm{O}_{2}$ concentration (1.0 mM) (Fig. 1B). Cell viability was recovered significantly with increasing concentrations of SMS from $0.05 \%-0.4 \%$ and leveled off at $75 \%$ of viability at SMS concentrations higher than $0.2 \%$ SMS. These results indicate that the antioxidant potential of $\mathrm{C} 2 \mathrm{C} 12$ myoblasts was definitely modulated by SMS pretreatment, and thus the cells were rescued from the death induced by $\mathrm{H}_{2} \mathrm{O}_{2}$ abuse. In addition, the preventive effect of SMS on $\mathrm{H}_{2} \mathrm{O}_{2}$ cytotoxicity was compared with $\alpha$-Toc and NAC, as antioxidant positive controls (Fig. 1C). Although the treatment of NAC significantly attenuated the cell death induced by $\mathrm{H}_{2} \mathrm{O}_{2}$, the protective potential of SMS was superior to that of NAC, while $\alpha$-Toc did not have any preventive effect on $\mathrm{H}_{2} \mathrm{O}_{2}$-induced cytotoxicity in $\mathrm{C} 2 \mathrm{C} 12$ cells. Since the recovering effect of SMS on $\mathrm{H}_{2} \mathrm{O}_{2}$-induced cell death was observed not only in $\mathrm{C} 2 \mathrm{C} 12$ myoblasts but also in PC-12 pheochromocytoma, Jurkat lymphoma, and A549 lung carcinoma cells (data not shown), it is suggested that the protective effect of SMS against $\mathrm{H}_{2} \mathrm{O}_{2}$ stress is a general phenomenon in different cell types.

\section{Apoptotic cell death}

It is well known that $\mathrm{H}_{2} \mathrm{O}_{2}$ derived oxidative stress induces apoptotic cell death in a variety of cell lines and also at tissue level. Here, we examined primary
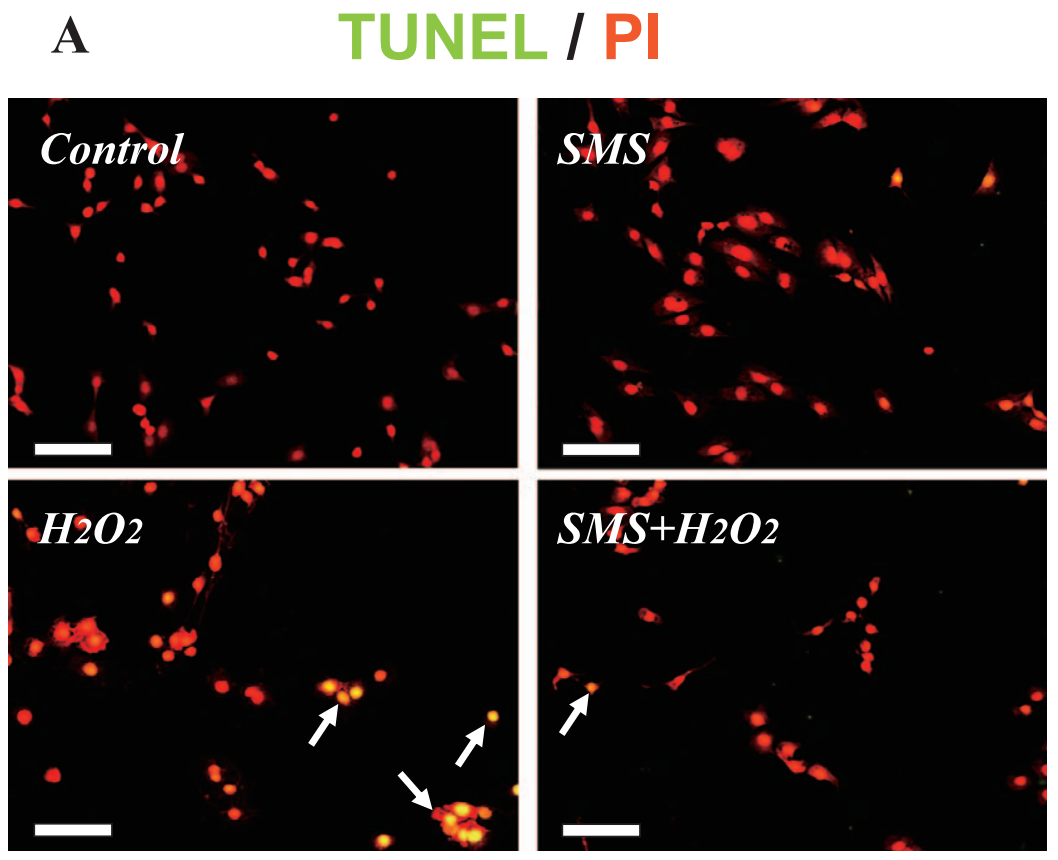

B
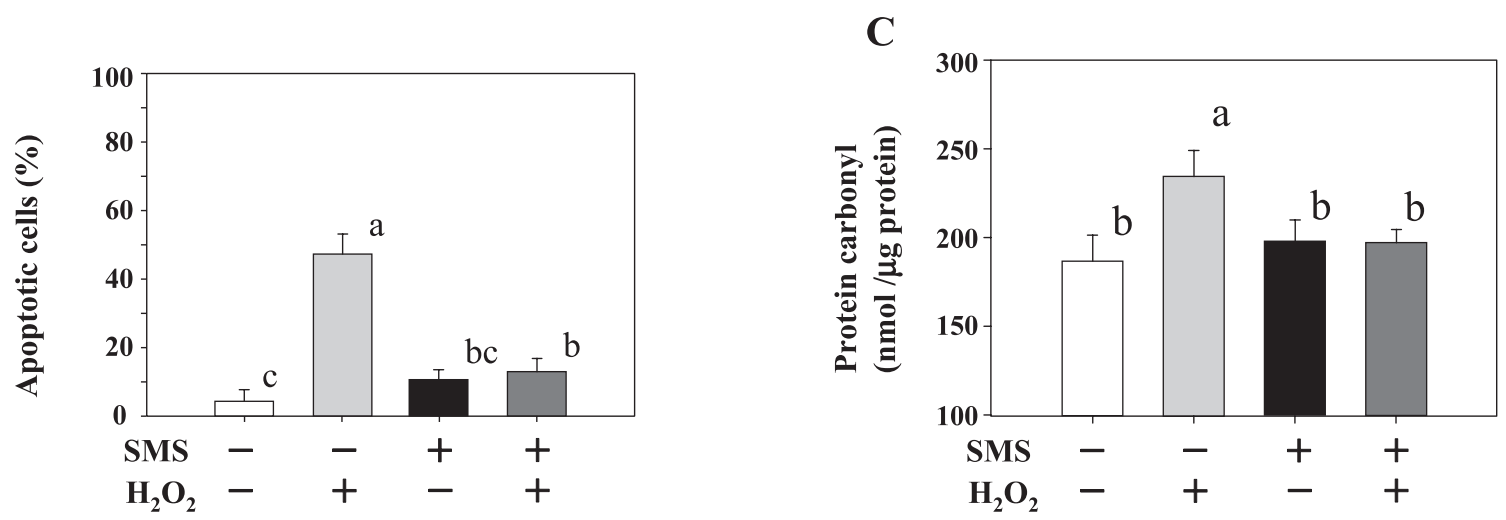

Fig. 2. Apoptotic cell death in $\mathrm{C} 2 \mathrm{C} 12$ myoblasts. After the pre-incubation with or without SMS for $24 \mathrm{~h}$, myoblasts cultures in Lab-Tec chamber slides were treated with or without $1 \mathrm{mM} \mathrm{H}_{2} \mathrm{O}_{2}$. Apoptotic cells were stained by the TUNEL method; subsequently, the cells were observed by a confocal laser microscope (A), and at least 500 cells in randomly selected 6 fields were counted (B). The amount of protein carbonyl was equalized by input of total protein and was determined (C). Each value represents the mean \pm S.D. obtained from at least quadruplicate determinations $\left({ }^{\text {abc }} P<0.05\right)$. 
apoptotic cell death by the TUNEL method (Fig. 2A). A few apoptotic cells $(5 \%)$ were observed even in the control culture, but the percentage of TUNEL-positive myoblasts was markedly increased to $47 \%$ after $1-\mathrm{h}$ treatment of $\mathrm{H}_{2} \mathrm{O}_{2}$ (Fig. 2B). SMS itself slightly increased the apoptotic cell rate (11\%) compared to the control culture, but the $\mathrm{H}_{2} \mathrm{O}_{2}$-induced cell death was significantly suppressed in the SMS-pre-treated myoblasts with the rate decreasing to as low as that of the 24h SMS (0.2\%)-pretreated cells without $\mathrm{H}_{2} \mathrm{O}_{2}$ abuse. The protective effect of SMS was also observed in the DNA breakage of $\mathrm{C} 2 \mathrm{C} 12$ myoblasts after $\mathrm{H}_{2} \mathrm{O}_{2}$ stress when determined by both the flow cytometric analysis of PI-stained sub-G1 cells and Agarose DNA fragmentation test (data not shown). These results indicated that SMS pre-incubation modified cellular potential against apoptotic cell death induced by $\mathrm{H}_{2} \mathrm{O}_{2}$.

\section{Protein carbonyl}

In order to estimate the extent of protein damage in $\mathrm{C} 2 \mathrm{C} 12$ myoblasts after oxidative abuse by $\mathrm{H}_{2} \mathrm{O}_{2}$, the content of protein carbonyl was measured (Fig. 2C). SMS itself did not alter the protein carbonyl level after the incubation for $24 \mathrm{~h}$ compared to the control culture. $\mathrm{H}_{2} \mathrm{O}_{2}$ abuse for $1 \mathrm{~h}$, however, significantly increased the protein carbonyl contents. $\mathrm{H}_{2} \mathrm{O}_{2}$-induced protein carbonyl formation was completely suppressed in SMS pre-treated cells. It was thus suggested that pre-incubation with SMS for $24 \mathrm{~h}$ modulated cellular antioxidant potential of $\mathrm{C} 2 \mathrm{C} 12$ myoblasts so as to resist to oxidative protein damage induced by $\mathrm{H}_{2} \mathrm{O}_{2}$.

\section{GPx activity}

GPx plays a major role in preventing free radical and ROS damages in numerous cells and is known to be expressed under oxidative stress $(24,25)$. The GPx activity was thus measured in cultures treated with SMS or $\mathrm{H}_{2} \mathrm{O}_{2}$ or both (Fig. 3). As expected, GPx activity was significantly enhanced after $\mathrm{H}_{2} \mathrm{O}_{2}$ abuse in $\mathrm{C} 2 \mathrm{C} 12$ myoblasts to approximately $135 \%$ of the control. The pre-incubation with SMS for $24 \mathrm{~h}$, on the other hand, significantly activated GPx in $\mathrm{C} 2 \mathrm{C} 12$ myoblasts to a level $28 \%$ higher than that of the control culture. However, no further enhancement of GPx activity occurred in the SMS pre-treated cells even after $\mathrm{H}_{2} \mathrm{O}_{2}$ treatment for $1 \mathrm{~h}$ and the activity level was maintained as low as $26 \%$. It was clearly indicated that the acquired cellular resistance of $\mathrm{C} 2 \mathrm{C} 12$ myoblasts against $\mathrm{H}_{2} \mathrm{O}_{2}$ abuse resulted from the constitutively enhanced GPx activity during the pre-incubation with SMS for $24 \mathrm{~h}$.

\section{Protein expression of GPX}

GPx expression at the protein level was further

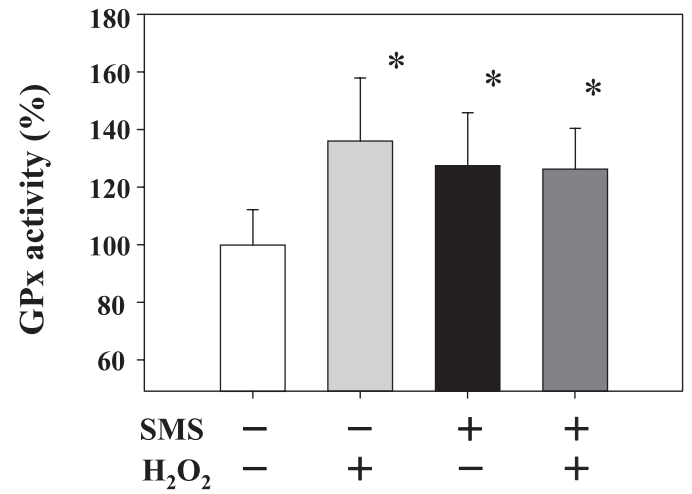

Fig. 3. GPx activity of $\mathrm{C} 2 \mathrm{C} 12$ myoblasts. After the pre-incubation with or without SMS for $24 \mathrm{~h}$, myoblasts cultures were treated with or without $1 \mathrm{mM} \mathrm{H}_{2} \mathrm{O}_{2}$. The percentage of GPX activity was compared to that in the control culture that was pre-incubated without SMS and treated without $\mathrm{H}_{2} \mathrm{O}_{2}$. Each value represents the mean \pm S.D. obtained from at least quadruplicate determinations $(* P<0.05)$

examined by immunohistochemical observation, immunoblot analysis, and ELISA using anti-GPx antibody (Fig. 4: A-D). A constitutive expression of GPx was observed in the control $\mathrm{C} 2 \mathrm{C} 12$ myoblasts culture shown by immunohistochemical (Fig. 4A) and immunoblot analysis (Fig. 4: B and C). After the pre-incubation with $0.2 \%$ SMS for $24 \mathrm{~h}$, the intracellular GPx protein in C2C12 myoblasts was increased (Fig 4: B and C) and widely distributed to the entire cell body as shown by the increased green fluorescence compared to the control culture (Fig. 4A). ELISA assay showed that the GPx protein was increased gradually with increasing time of pre-incubation with SMS and became saturated after $24-48 \mathrm{~h}$ of incubation (Fig. 4D). Indeed, the induction of GPx protein by SMS was statistically significant at 24 and $48 \mathrm{~h}$. These data indicate that the enhanced resistance of $\mathrm{C} 2 \mathrm{C} 12$ myoblasts against oxidative stress was due to the GPx protein expression manipulated by SMS pre-incubation.

\section{$m R N A$ expression of $G P x$}

GPx expression in cultured $\mathrm{C} 2 \mathrm{C} 12$ myoblasts was further examined at the gene transcriptional level. GPx mRNA expression was detected in all the cultures of $\mathrm{C} 2 \mathrm{C} 12$ myoblasts as a PCR product of $0.43 \mathrm{~kb}$ by RT-PCR (Fig. 5A), and thus the expression levels were quantified with the band by real-time RT-PCR (Fig. 5B). When $\mathrm{C} 2 \mathrm{C} 12$ myoblasts were treated with $\mathrm{H}_{2} \mathrm{O}_{2}$, GPx mRNA expression was significantly enhanced by $42 \%$ compared to the level in control culture. SMS pretreatment itself also caused weak induction by $23 \%$ compared to the control. However, subsequent $\mathrm{H}_{2} \mathrm{O}_{2}$ abuse to the SMS pre-treated culture for $1 \mathrm{~h}$ did not 

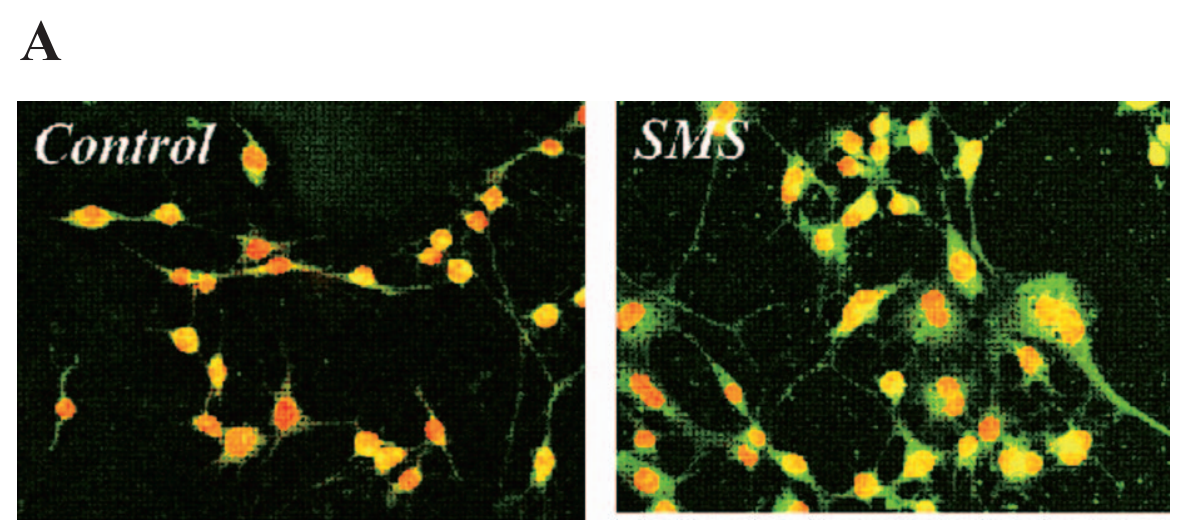

B

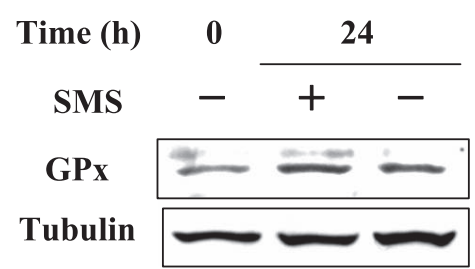

C

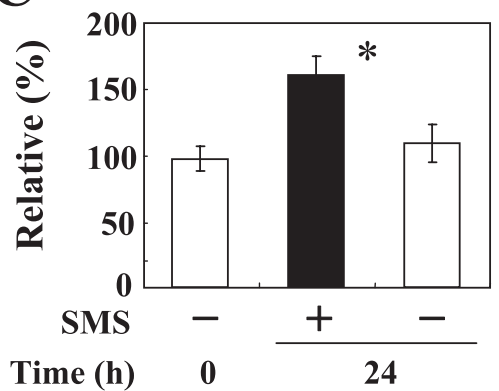

D

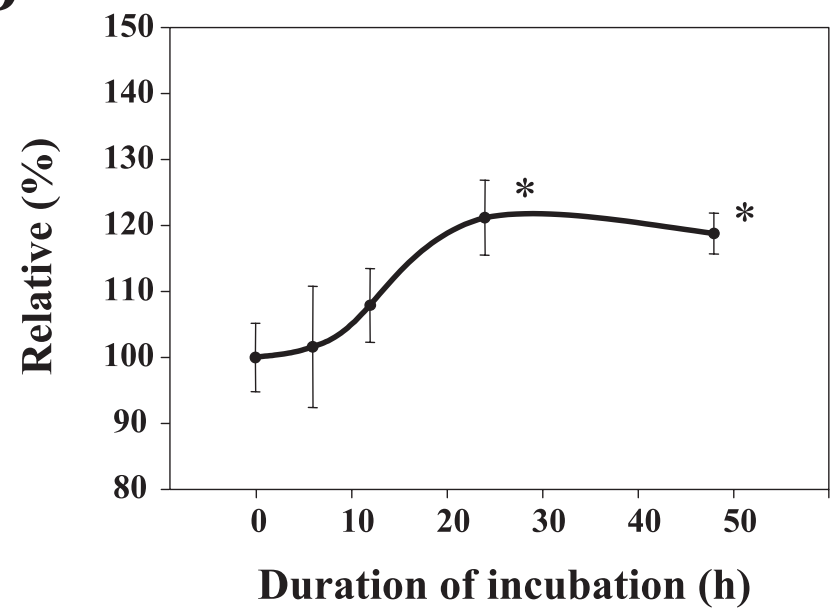

Fig. 4. GPx expression in $\mathrm{C} 2 \mathrm{C} 12$ myoblasts. After the pre-incubation with or without SMS for $24 \mathrm{~h}$, myoblasts cultures in $\mathrm{Lab}-\mathrm{Tec}$ chamber slides were treated with or without $1 \mathrm{mM} \mathrm{H}_{2} \mathrm{O}_{2}$. Chambers were processed for indirect immunofluorescence assay with anti-GPx antibody and secondary antibody conjugated with FITC and subsequently counterstained with Propidium iodide (PI). Specimens were observed by a confocal laser microscope (A). Intracellular GPx in C2C12 myoblasts was estimated by immunobloting using anti-GPx antibody before and after incubation with SMS (B). The expression level of GPx was digitized by using NIH-image software and standardized by tubulin (C). Equal amount of protein, which was harvested at the indicated time, was applied and determined by the ELISA system using the same antibodies (D). Each value represents the mean \pm S.D. obtained from at least quadruplicate determinations $(* P<0.05)$.

induce further increase in the GPx mRNA expression (26\%). The increased GPx mRNA expression by $\mathrm{H}_{2} \mathrm{O}_{2}$ was completely inhibited in SMS treated cells. This result was well consistent with those of the enzyme activity and protein expression profile of GPx (Figs. 3 and 4). Notably, the mRNA expression level of PH-GPx (GPx-3), another subtype of GPx, was also determined but it was not altered under the same conditions (data not shown). This indicates that the improved modulation of the antioxidant potential of $\mathrm{C} 2 \mathrm{C} 12$ myoblast by SMS 
A

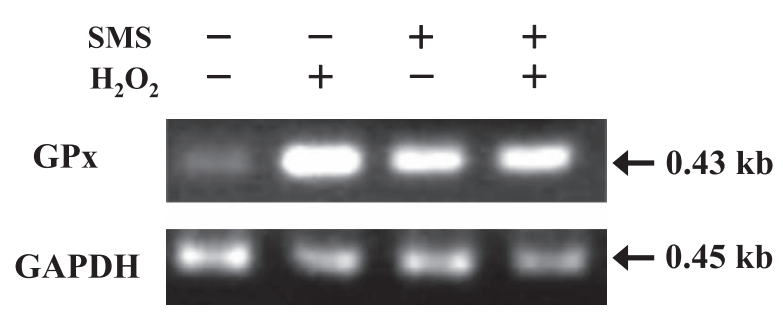

B

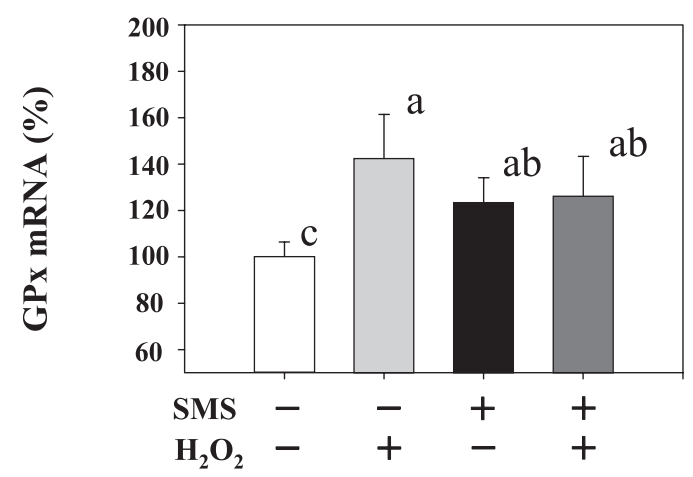

Fig. 5. mRNA expression of GPx in $\mathrm{C} 2 \mathrm{C} 12$ myoblasts. GPx mRNA expression was studied by quantitative real-time RT-PCR using total cellular RNA from cultures that were incubated with or without SMS and treated with or without $\mathrm{H}_{2} \mathrm{O}_{2}$. To equalize input of total RNA, the level of RNA for the constitutively expressed GAPDH was determined (A) and digitized by Smart Cycler system software (B). PCR reaction was performed under conditions of linearity with respect to input RNA. PCR amplification was performed in quadruplicate. Each value represents the mean \pm S.D. obtained from at least quadruplicate determinations $\left({ }^{\text {abc }} P<0.05\right)$.

was due to an increase of cellular GPx at the transcriptional level.

\section{GSH levels}

The intracellular GSH level critically reflects cellular redox status. It is expected that GSH consumption is facilitated under the oxidative stress condition in which GPx uses GSH as the substrate to protect cells against free radicals such as $\mathrm{OH}^{-}, \mathrm{O}_{2}^{-}$, and $\mathrm{ONOO}^{-}(12,13)$. We, therefore, determined the intracellular GSH level by the use of MBCL as a fluorescent probe (Fig. 6). Although SMS pre-incubation did not alter intracellular GSH level, it was significantly decreased after treating the cells with $1.0 \mathrm{mM} \mathrm{H}_{2} \mathrm{O}_{2}$ as expected. GSH level in SMS pre-treated cells was decreased more significantly by additional treatment of cells with $1 \mathrm{mM} \mathrm{H}_{2} \mathrm{O}_{2}$. The decreased extent of GSH level was even greater than that observed in myoblasts treated with only $\mathrm{H}_{2} \mathrm{O}_{2}$. This result indicates that the enhanced GPx activity observed in the SMS pre-treated cells facilitated the intracellular

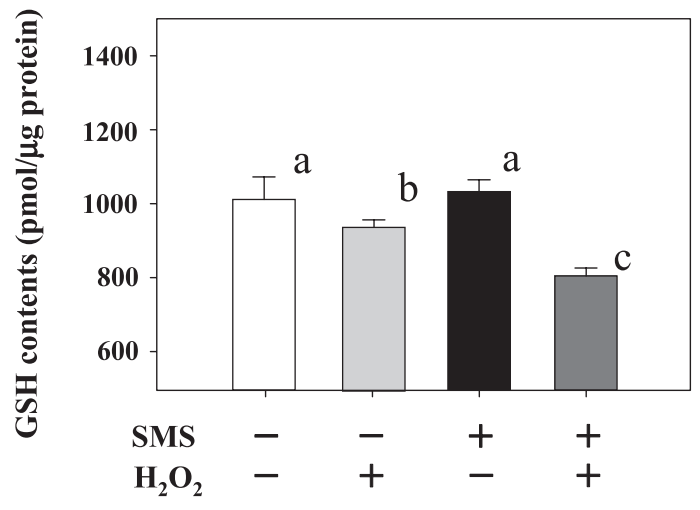

Fig. 6. GSH contents of $\mathrm{C} 2 \mathrm{C} 12$ myoblasts. After the pre-incubation with or without SMS for $24 \mathrm{~h}$, myoblast cultures were treated with or without $1 \mathrm{mM} \mathrm{H}_{2} \mathrm{O}_{2}$. To equalize input of total protein, the cellular protein was determined. Each value represents the mean \pm S.D. obtained from at least quadruplicate determinations ( $\left.{ }^{\text {abc }} P<0.05\right)$.

GSH consumption after $\mathrm{H}_{2} \mathrm{O}_{2}$ abuse in order to protect the cells from oxidative stress.

\section{Discussion}

The muscle disorders such as muscular dystrophy are associated with an increase of oxidative stress (3-6). There are many clinical trials proposed for muscular dystrophy treatments such as gene therapy and transplantation of myoblasts $(7,8)$. On the other hand, skeletal muscle, either normal muscle or myoblast, is susceptible to oxidative stress that can be easily induced in normal muscles and myoblasts through the rapid changes in energy supply and oxygen flux during the contraction (9) or through extreme exercises $(10,11)$. Therefore, antioxidative protection of cells is one of the basic strategies to control the oxidative muscle injury and its related disease conditions. Here we demonstrated the way to modulate inherent cellular defensive potential against oxidative stress by SMS. SMS is a traditional herbal medicine formula that has been used for more than eight hundred years in China and is comprised of three herbs, Panax ginseng, Fructus schisandrae, and Radix ophipogonis. SMS is traditionally used for the treatment of excessive loss of essence Qi and body fluid and is currently prescribed for treating coronary heart diseases (26).

We previously showed that the preceding injection of SMS into duodenum to cerebral ischemia-reperfusion in rats prevented the loss of GPx activity, increase of protein carbonyl, and accumulation of lipid peroxide in brain and other tissues and thus finally alleviated the oxidative tissue injury caused by ischemia-reperfusion (17). The modulation and maintenance of tissue GPx activity by SMS treatment suggested that the preventive 
effect of SMS was not only due to the radical scavenging activity but also due to modulation of antioxidative cellular response. The present study further revealed that $\mathrm{C} 2 \mathrm{C} 12$ myoblasts, when pre-incubated with SMS, acquired the resistance to oxidative stress induced by $\mathrm{H}_{2} \mathrm{O}_{2}$ treatment; indeed, myoblasts that were preincubated with SMS and then subjected to $\mathrm{H}_{2} \mathrm{O}_{2}$ at the concentration of $0.5-1 \mathrm{mM}$ showed significantly increased cell viability compared to the cells not pretreated with SMS (Fig. 1A). Since the extracellular SMS was washed out before $\mathrm{H}_{2} \mathrm{O}_{2}$ abuse, the protective effect of SMS on myoblasts against oxidative stress was not due to the direct scavenging of $\mathrm{H}_{2} \mathrm{O}_{2}$ by SMS in culture media, even though SMS has radical scavenging activity by itself in vitro (26). This is consistent with our previous observation in that DNA damage protection and repair in $\mathrm{H}_{2} \mathrm{O}_{2}$-treated $\mathrm{PC}-12$ cells was attained by the preceding SMS treatment depending on the pre-incubation period (27). In the preliminary study, the improving effect of SMS was dependent on the length of the preincubation period and maximized after $24 \mathrm{~h}$, and then it was constitutively maintained thereafter (data not shown). Thus, the following experiments were conducted with 24-h pre-incubation with SMS and the $\mathrm{H}_{2} \mathrm{O}_{2}$ concentration of $1 \mathrm{mM}$. $\mathrm{H}_{2} \mathrm{O}_{2}$-induced cell death of $\mathrm{C} 2 \mathrm{C} 12$ myoblasts was significantly inhibited by SMS treatment, although the recovery of cell viability was saturated with SMS concentration higher than $0.2 \%$ (Fig. 1B). The inhibitory effect of SMS on $\mathrm{H}_{2} \mathrm{O}_{2}$-induced cytotoxicity was superior to that of NAC or $\alpha$-Toc, known to have an antioxidant activity $(28-30)$, treated cells. SMS, therefore, has more ability than the other antioxidants to modulate the antioxidative potential of $\mathrm{C} 2 \mathrm{C} 12$ myoblasts against $\mathrm{H}_{2} \mathrm{O}_{2}$ abuse. The details of this mechanism in the $\mathrm{C} 2 \mathrm{C} 12$ myoblasts were precisely examined under the experimental condition with 24-h pre-incubation with $0.2 \%$ SMS and $1 \mathrm{mM}$ of $\mathrm{H}_{2} \mathrm{O}_{2}$ treatment.

It is commonly recognized that GPx plays a major role in the prevention of oxidative stress induced by free radical and ROS using GSH as the co-substrate $(12-14)$, while the expression of intracellular GPx is induced in many cell types under the oxidative stress $(24,25)$. It was also observed in the present study that both the activity and mRNA expression of GPx were significantly enhanced in $\mathrm{C} 2 \mathrm{C} 12$ myoblasts by $\mathrm{H}_{2} \mathrm{O}_{2}$ treatment for $1 \mathrm{~h}$ (Figs. 3 and 5), although it was no longer effective on the attenuation of the protein carbonyl, as an index of protein damage (Fig. 2C), and the number of the apoptotic cells (Fig. 2: A and B).

Increase of ROS level occurred under the oxidative stress condition and is sensed by redox-sensitive regulatory molecules such as thioredoxin in the cell, triggering homeostatic responses to prevent cellular injury (31). Franco et al. reported that mRNA expression of antioxidant enzymes was increased in muscle cells under oxidative stress, and the extent was correlated to the level of oxidative injury to cells (24). Chan et al. suggested that the levels and balance of antioxidant enzymes determine the susceptibility of muscle cells against oxidative injury (9). Indeed, it has been reported that the role of GPx is critical and the nerve cells overexpressing GPx showed higher resistance against $\mathrm{H}_{2} \mathrm{O}_{2}$ injury mediated by amyloid-beta $(32,33)$. In addition, we previously reported that SMS prevented the cell death induced by amyloid-beta in PC-12 with increasing intracellular GPx induction (18). In the present study, however, the induction of GPx activity by $\mathrm{H}_{2} \mathrm{O}_{2}$ treatment is not responsible for increasing the antioxidative potential of $\mathrm{C} 2 \mathrm{C} 12$ myoblasts in view of the cell viability. It was shown, however, the induced GPx during the pre-incubation with SMS prior to $\mathrm{H}_{2} \mathrm{O}_{2}$ abuse inhibited oxidative injury and death of myoblasts in a dose-dependent manner (Fig. 1), that is, protein carbonyl accumulation (Fig. 2C) and increasing percentage of apoptotic cells (Fig. 2: A and B) were prevented. These observations were consistent with the results reported in other studies $(17,27)$ and suggest that SMS modulated the cellular redox status by enhancing the expression of GPx prior to $\mathrm{H}_{2} \mathrm{O}_{2}$ abuse. Thus, it was considered that the constitutive induction of the cellular GPx is necessary for the defense against the oxidative injury and its accumulation caused by ROS.

We ascertained that the intracellular GSH content was decreased in SMS pre-incubated culture more greatly than in the culture without SMS (Fig. 6). GSH plays a major role in cellular antioxidant defense, and thus the depletion of cellular GSH has been shown to increase the sensitivity of cells towards the toxic effects of ROS $(34-36)$. It works not only as a strong free radical scavenger but also as a co-substrate of $\operatorname{GPx}(37,38)$. It is thus indicated that the significant decrease of cellular GSH after $\mathrm{H}_{2} \mathrm{O}_{2}$ treatment observed in the SMS-preincubated myoblast cells resulted from the enhanced expression of GPx during the pre-incubation with SMS for $24 \mathrm{~h}$. Since the de novo synthesis of GSH takes several hours (39), these results implicate that improved GPx level by SMS is more critical to suppress the oxidative tissue injury and following apoptotic cell death of C2C12 myoblasts. This also explains the observation that the decreased viability of cells was not effectively attenuated by SMS at the higher $\mathrm{H}_{2} \mathrm{O}_{2}$ concentration $(>2 \mathrm{mM})$ (Fig. 1A), presumably because the availabilities of total GSH, as co-substrate for GPx and radical scavenger, were limited under the culture condition. 
In conclusion, a constitutively enhanced GPx expression by SMS pre-incubation is valuable for protecting myoblasts against the oxidative cell damage. The present study defines the potential benefit of using herbal medicines as a multifunctional formula to treat oxidative stress in muscle and offers a new potent tool to optimize future cell therapy protocols such as treatments for the muscular dystrophies. Although we focused on GPx induction in myoblasts and showed the protective function in oxidative injury of cells in the present study, further study of SMS still remains and the antioxidative modulation in the various kinds of pathways involving other antioxidative enzymes and cellular components that have potentials such as free radical activity needs to be clarified because most of the antioxidative molecules have complex cross-talks in signal transduction pathways during the oxidative stress condition.

\section{Acknowledgments}

The mRNA expression of GPx was performed and supported by Niigata Bio Research Park, Niigata and Niigata Division, Nihon Rinsho Co., Niigata. We thank Kotaro Pharmaceutical Co., Ltd. for providing materials for the preparation of Shengmai-san. The present study was supported in part by a grant from the promotion and mutual aid corporation for private schools in Japan.

\section{References}

1 Jackson MJ, O'Farrell S. Free radicals and muscle damage. $\mathrm{Br}$ Med Bull. 1993;49:630-641.

2 Koenig M, Hoffman EP, Bertelson CJ, Monaco AP, Feener C, Kunkel LM. Complete cloning of the Duchenne muscular dystrophy (DMD) cDNA and preliminary genomic organization of the DMD gene in normal and affected individuals. Cell. 1987;50:509-517.

3 Rodriguez MC, Tarnopolsky MA. Patients with dystrophinopathy show evidence of increased oxidative stress. Free Radic Biol Med. 2003;34:1217-1220.

4 Wang NL, Liou YL, Lin MT, Lin CL, Chang CK. Chinese herbal medicine, Shengmai San, is effective for improving circulatory shock and oxidative damage in the brain during heatstroke. J Pharmacol Sci. 2005;97:253-265.

5 Haycock JW, Mac Neil S, Mantle D. Differential protein oxidation in Duchenne and Becker muscular dystrophy. Neuroreport. 1998;9:2201-2207.

6 Haycock JW, MacNeil S, Jones P, Harris JB, Mantle D. Oxidative damage to muscle protein in Duchenne muscular dystrophy. Neuroreport. 1996;8:357-361.

7 Qu-Petersen Z, Deasy B, Jankowski R, Ikezawa M, Cummins J, Pruchnic R, et al. Identification of a novel population of muscle stem cells in mice: potential for muscle regeneration. J Cell Biol. 2002;157:851-864.

8 Huard J, Cao B, Qu-Petersen Z. Muscle-derived stem cells: potential for muscle regeneration. Birth Defects Res C Embryo
Today. 2003;69:230-237.

9 Chan KM, Decker EA. Endogenous skeletal muscle antioxidants. Crit Rev Food Sci Nutr. 1994;34:403-426.

10 Davies KJ, Quintanilha AT, Brooks GA, Packer L. Free radicals and tissue damage produced by exercise. Biochem Biophys Res Commun. 1982;107:1198-1205.

11 Walker PM. Ischemia/reperfusion injury in skeletal muscle. Ann Vasc Surg. 1991;5:399-402.

12 Berendji D, Kolb-Bachofen V, Meyer KL, Kroncke KD. Influence of nitric oxide on the intracellular reduced glutathione pool: different cellular capacities and strategies to encounter nitric oxide-mediated stress. Free Radic Biol Med. 1999;27:773780.

13 Flohe L, Gunzler WA, Schock HH. Glutathione peroxidase: a selenoenzyme. FEBS Lett. 1973;32:132-134.

14 Masaki H, Okano Y, Sakurai H. Differential role of catalase and glutathione peroxidase in cultured human fibroblasts under exposure of $\mathrm{H} 2 \mathrm{O} 2$ or ultraviolet B light. Arch Dermatol Res. 1998;290:113-118.

15 Ou B, Huang D, Hampsch-Woodill M, Flanagan JA. When east meets west: the relationship between yin-yang and antioxidation-oxidation. Faseb J. 2003;17:127-129.

16 Wang NL, Chang CK, Liou YL, Lin CL, Lin MT. Shengmai San, a Chinese herbal medicine protects against rat heat stroke by reducing inflammatory cytokines and nitric oxide formation. J Pharmacol Sci. 2005;98:1-7.

17 Xuejiang W, Magara T, Konishi T. Prevention and repair of cerebral ischemia-reperfusion injury by Chinese herbal medicine, shengmai san, in rats. Free Radic Res. 1999;31:449-455.

18 Nishida H, Kushida M, Nakajima Y, Ogawa Y, Tatewaki N, Sato S, et al. Amyloid-beta-induced cytotoxicity of PC-12 cell was attenuated by Shengmai-san through redox regulation and outgrowth induction. J Pharmacol Sci. 2007;104:73-81.

19 Hansen MB, Nielsen SE, Berg K. Re-examination and further development of a precise and rapid dye method for measuring cell growth/cell kill. J Immunol Methods. 1989;119:203-210.

20 Levine RL, Williams JA, Stadtman ER, Shacter E. Carbonyl assays for determination of oxidatively modified proteins. Methods Enzymol. 1994;233:346-357.

21 Wendel A. Glutathione peroxidase. Methods Enzymol. 1981; 77:325-333.

22 Liu ZX, Nishida H, He JW, Lai MM, Feng N, Dennert G. Hepatitis $\mathrm{C}$ virus genotype $1 \mathrm{~b}$ core protein does not exert immunomodulatory effects on virus-induced cellular immunity. J Virol. 2002;76:990-997.

23 Fernandez-Checa JC, Kaplowitz N. The use of monochlorobimane to determine hepatic GSH levels and synthesis. Anal Biochem. 1990;190:212-219.

24 Franco AA, Odom RS, Rando TA. Regulation of antioxidant enzyme gene expression in response to oxidative stress and during differentiation of mouse skeletal muscle. Free Radic Biol Med. 1999;27:1122-1132.

25 Michiels C, Raes M, Toussaint O, Remacle J. Importance of Se-glutathione peroxidase, catalase, and $\mathrm{Cu} / \mathrm{Zn}-\mathrm{SOD}$ for cell survival against oxidative stress. Free Radic Biol Med. 1994;17:235-248.

26 Ichikawa $\mathrm{H}$, Konishi $\mathrm{T}$. In vitro antioxidant potentials of traditional Chinese medicine, Shengmai San and their relation to in vivo protective effect on cerebral oxidative damage in rats. Biol Pharm Bull. 2002;25:898-903. 
27 Wang L, Nishida H, Ogawa Y, Konishi T. Prevention of oxidative injury in PC12 cells by a traditional Chinese medicine, Shengmai San, as a model of an antioxidant-based composite formula. Biol Pharm Bull. 2003;26:1000-1004.

28 Gillissen A, Jaworska M, Orth M, Coffiner M, Maes P, App EM, et al. Nacystelyn, a novel lysine salt of $\mathrm{N}$-acetylcysteine, to augment cellular antioxidant defence in vitro. Respir Med. 1997;91:159-168.

29 Sasaki N, Baba N, Matsuo M. Cytotoxicity of reactive oxygen species and related agents toward undifferentiated and differentiated rat phenochromocytoma PC12 cells. Biol Pharm Bull. 2001;24:515-519.

30 Zaniew M, Zachwieja J, Warzywoda A, Stefaniak E, Runowski D, Lewandowska-Stachowiak M. Influence of vitamin E and Nacetylcysteine on intracellular oxidative stress in $\mathrm{T}$ lymphocytes in children treated with dialysis. Wiad Lek. 2005;58 Suppl 1:5865.

31 Schreck R, Baeuerle PA. Assessing oxygen radicals as mediators in activation of inducible eukaryotic transcription factor NFkappa B. Methods Enzymol. 1994;234:151-163.

32 Sagara Y, Dargusch R, Klier FG, Schubert D, Behl C. Increased antioxidant enzyme activity in amyloid beta protein-resistant cells. J Neurosci. 1996;16:497-505.

33 Barkats M, Millecamps S, Abrioux P, Geoffroy MC, Mallet J.
Overexpression of glutathione peroxidase increases the resistance of neuronal cells to Abeta-mediated neurotoxicity. J Neurochem. 2000;75:1438-1446.

34 Wink DA, Nims RW, Darbyshire JF, Christodoulou D, Hanbauer I, Cox GW, et al. Reaction kinetics for nitrosation of cysteine and glutathione in aerobic nitric oxide solutions at neutral $\mathrm{pH}$. Insights into the fate and physiological effects of intermediates generated in the $\mathrm{NO} / \mathrm{O} 2$ reaction. Chem Res Toxicol. 1994;7:519-525.

35 Walker MW, Kinter MT, Roberts RJ, Spitz DR. Nitric oxideinduced cytotoxicity: involvement of cellular resistance to oxidative stress and the role of glutathione in protection. Pediatr Res. 1995;37:41-49.

36 Luperchio S, Tamir S, Tannenbaum SR. NO-induced oxidative stress and glutathione metabolism in rodent and human cells. Free Radic Biol Med. 1996;21:513-519.

37 Deneke SM, Fanburg BL. Regulation of cellular glutathione. Am J Physiol. 1989;257:L163-L173.

38 Sies H. Strategies of antioxidant defense. Eur J Biochem. 1993;215:213-219.

39 Kojima S, Ishida H, Takahashi M, Yamaoka K. Elevation of glutathione induced by low-dose gamma rays and its involvement in increased natural killer activity. Radiat Res. 2002; 157:275-280. 